\title{
Politik Hukum di Kawasan Hutan dan Lahan bagi Masyarakat Hukum Adat
}

Destara Sati ${ }^{1}$

\begin{abstract}
Abstrak
Masyarakat hukum adat sebagai bagian dari bangsa Indonesia menjadi salah satu subjek yang paling terdampak dari kebijakan terkait hutan dan lahan. Dengan membaca tren muatan peraturan perundang-undangan yang diundangkan oleh pemerintah di sektor kehutanan dan lahan, dapat dilihat arah kebijakan yang dibuat apakah semakin meminggirkan hak-hak tradisional masyarakat hukum adat ataukah menempatkan masyarakat hukum adat sebagai bagian dari bangsa Indonesia yang berhak atas wilayahnya. Dengan membaca tren muatan peraturan perundang-undangan di kawasan hutan dan lahan, pula dapat dipetakan keberpihakan pemerintah terhadap keberadaan masyarakat hukum adat yang berada di kawasan hutan dan lahan, di mana hal tersebut seringkali menimbulkan konflik.

Kata kunci: Masyarakat Hukum Adat; Tren Muatan Peraturan Perundang-undangan Di Kawasan Hutan dan Lahan; Politik Hukum Atas Keberadaan Masyarakat Hukum Adat di Kawasan Hutan dan Lahan.
\end{abstract}

\begin{abstract}
Masyarakat Hukum Adat as part of the Indonesian nation is one of the most affected subjects of forest and land related policies. By reading the trends in the content of legislation issued by the Government in the forestry and land sector, it can be seen the direction of policy that is made whether to marginalize the traditional rights of Masyarakat Hukum Adat or to place customary communities as part of the Indonesian nation entitled to their territory. By reading the trends in the content of laws and regulations in the forest and land areas, agrarian conflicts can also be mapped that happend to indigenous peoples over their territories in forest and land areas. The political year which is rife with the permit to release the license to borrow and use the forest area has also exacerbated forest and land tenure conflicts. By reading the legal politics in the forest and land area, it can be traced the juridical and political traces that the Government has strived to maintain the survival of Masyarakat Hukum Adat.

Keyword: Masyarakat Hukum Adat; The trends in the content of laws and regulation in the forest and land areas; Legal politics of Masyarakat Hukum Adat in forest and land areas.
\end{abstract}

${ }^{1}$ Penulis adalah Mahasiswa Magister Hukum Lingkungan dan Sumber Daya Alam Fakultas Hukum, Universitas Indonesia. 


\section{Pendahuluan}

Persoalan agraria telah ada sejak masa kolonial. Pemerintah telah membangun dasar-dasar bagi perombakan struktur agraria kolonial, menciptakan tatanan hukum baru dan melancarkan program land reform untuk melaksanakan perombakan tersebut. Namun upaya tersebut tidak berhasil sepenuhnya. Rezim Orde Baru memutar balik arah politik hukum agraria, semula berorientasi pada perombakan struktur penguasaan tanah untuk menciptakan pemerataan, menjadi berorientasi pada efisiensi, pertumbuhan ekonomi, dan ekstraksi Sumber Daya Alam (SDA). Orientasi ini mengakibatkan konflik agraria semakin meningkat, masif dan meluas.

Pasca Orde Baru terdapat upaya melakukan koreksi terhadap kebijakan yang dipraktikkan oleh rezim sebelumnya. ${ }^{2}$ Salah satunya melalui pembentukan TAP MPR No. IX/MPR/2001 tentang Pembaruan Agararia dan Pengelolaan SDA. Amanah dari TAP MPR tersebut untuk melakukan kaji ulang semua peraturan perundang-undangan di bidang agraria dan pengelolaan SDA. Namun, pemerintah dan DPR mengabaikannya dan melakukan pola fragmentasi legislasi di bidang SDA. ${ }^{3}$
Pada periode ini, lebih dari tiga puluh undang-undang (UU) yang berkaitan dengan tanah dan SDA lainnya. Kebanyakan dari UU tersebut memperkenalkan skema-skema pemanfaatan baru melalui model perizinan yang diberikan oleh pemerintah pada tingkat pusat dan daerah. Fragmentasi pengaturan agraria semakin banyak dan menjauh dari semangat yang sebelumnya pernah ada dalam UUPA. ${ }^{4}$ Pembaruan hukum pada masa reformasi banyak dipengaruhi oleh intervensi asing, khususnya International Monetery Fund (IMF) melalui letter of intents (LoI). Sebagian besar UU yang dibentuk adalah untuk memfasilitasi semakin berkembangnya ekstraksi SDA. ${ }^{5}$ Konstelasi peraturan yang demikian diikuti dengan kebijakan untuk mengintegrasikan sistem perekonomian Indonesia dengan sistem perekonomian global melalui Program Masterplan Percepatan dan Perluasan Pembangunan Ekonomi Indonesia (MP3EI) yang berorientasi pada pembangunan infrastruktur dan pengembangan industri pangan serta energi berbasiskan pada kekuatan modal. Upaya legalisasi tanah semakin diperluas untuk memberikan kepastian bagi bekerjanya modal pada tanah air Indonesia. ${ }^{6}$

\footnotetext{
2 Yance Arizona, Konstitusionalisme Agraria, (Yogyakarta: STPN Press, 2014), 2014, hlm. 400-401.

${ }^{3}$ Ibid., hlm. 159.

${ }^{4}$ Ibid., hlm. 164.

${ }^{5}$ Ibid., hlm. 190.

${ }^{6}$ Ibid.
} 
Ketimpangan penguasaan lahan dan hutan semakin melebar. Hal ini merupakan faktor utama terjadinya konflik. Pada tahun 2003, BPN menggambarkan situasi ketimpangan tersebut dengan mengeluarkan data bahwa mayoritas petani $(84 \%)$ menguasai tanah pertanian kurang dari satu hektare dan hanya 16\% yang menguasai tanah lebih dari satu hektare. ${ }^{7}$ Sementara itu terjadi ketimpangan alokasi pemanfaatan sumber daya hutan. Hutan Tanaman Industri (HTI) mencapai 9,39 juta hektare untuk 262 unit perusahaan, HPH untuk 21,49 juta hektare untuk 303 unit perusahaan, yang berbanding sangat sedikit dengan Hutan Tanaman Rakyat (HTR) yang hanya seluas 631.628 hektare. Di bidang perkebunan, Pemerintah memberikan 9,4 juta hektar untuk 600 perusahaan perkebunan kelapa sawit. ${ }^{8}$ Data terbaru diluncurkan Fakultas Kehutanan Universitas Gajah Mada (UGM) (25/10/18), terkait hasil pengolahan data perkebunan sawit yang berada di kawasan hutan dan ilegal. Temuannya, seluas 2,8 juta hektare kebun sawit berada di kawasan hutan, 35\% dikuasai masyarakat dan $65 \%$ pengusaha. Izin pelepasan dan izin pinjam pakai kawasan hutan pun pada beberapa kasus tak melalui skema perizinan reguler atau ilegal. Dari jumlah itu, sekitar 35\% merupakan kebun masyarakat, sisanya, dikelola perusahaan. ${ }^{9}$

Salah satu jalan keluar yang dianggap dapat menyelesaikan persoalan ketimpangan penguasaan lahan ini adalah dengan mengakomodasi pengelolaan lahan oleh masyarakat, misalnya melalui perhutanan sosial. KLHK mencatat skema perhutanan sosial berperan dalam memperbaiki ketimpangan pemanfaatan hutan. Sebelum ada skema perhutanan sosial, perusahaan memiliki menguasai hutan $98 \%$, sementara masyarakat hanya $2 \%$. Setelah diberlakukan skema perhutanan sosial, terdapat perbaikan proporsi, yakni 69\%-72\% untuk perusahaan dan 28\%-31\% untuk masyarakat. ${ }^{10}$ Namun demikian, klaim tersebut tidak bisa dijadikan satu-satunya basis keberhasilan perbaikan ketimpangan penguasaan hutan dan lahan. Hal ini disebabkan karena masih ditemuinya persoalan di lapangan terkait dengan aspek kelembagaan dan tumpang tindih perizinan yang menghambat percepatan perhutanan sosial.

\footnotetext{
7 Yance Arizona, Konstitusionalisme Agraria, (Yogyakarta: STPN Press, 2014), hlm. 401.

${ }^{8}$ Ibid., hlm. 402.

9 Tommy Apriando, “ Kajian UGM: 2,8 Juta Hektar Kebun Sawit di Kawasan Hutan, 65\% Milik Pengusaha, Solusinya?http:/ / www.mongabay.co.id/2018/11/04/kajian-ugm-28-juta-hektar-kebunsawit-di-kawasan-hutan- 65-milik-pengusaha-solusinya/, diakses tanggal 28 November 2018.

10 Danu Damarjati, "Menteri LHK Beberkan Hasil Atasi Ketimpangan Penguasaan Hutan”. https:/ / news.detik.com/berita/d-3952129/menteri-lhk-beberkan-hasil-atasi-ketimpangan-penguasa an-hutan, diakses tanggal 23 April 2019.
} 
Ketimpangan penguasaan hutan dan lahan juga menyebabkan konflik yang memiliki empat karakteristik. Pertama, bersifat kronis, masif dan meluas, berdimensi hukum, sosial, politik, dan ekonomi. Kedua, struktural, di mana penyebab utamanya terjadi dikarenakan kebijakan-kebijakan pemerintah dalam penguasaan dan penggunaan tanah serta pengelolaan SDA. Ketiga, penerbitan izin-izin usaha penggunaan tanah dan pengelolaan SDA tidak menghormati keberagaman hukum yang menjadi dasar hak tenurial masyarakat. Keempat, merupakan pelanggaran HAM. ${ }^{11}$ Situasi tersebut menghendaki perlu dilakukan penataan ulang penguasaan, pemilikan, peruntukan, dan penggunaan tanah dan SDA lainnya. Pada titik itulah reforma agraria menjadi relevan.

Tingginya konflik dalam pengelolaan SDA yang terjadi di Indonesia disebabkan oleh adanya ketimpangan penguasaan SDA antara masyarakat yang menggantungkan hidup dari SDA dengan penguasaan oleh sektor industri, terutama perkebunan, kehutanan, pertambangan, dan penguasaan oleh Negara yang masih menegasi adanya hak-hak masyarakat adat. Terdapat sekitar 70 juta anggota Masyarakat Hukum Adat (MHA), atau sekitar 20\% dari total penduduk Indone- sia yang tersebar di seluruh nusantara, yang mana lebih dari separuhnya hidup dan bergantung dari sumber daya di kawasan hutan dan lahan. ${ }^{12}$

Permasalahan yang akan dibahas dan dielaborasi dalam penelitian ini adalah bagaimana politik hukum di kawasan hutan dan lahan dalam konsep hak menguasai negara ditelusuri melalui jejak yuridis sejak zaman kolonial hingga saat ini.

\section{Hak Menguasai Negara}

Penguasaan negara atas SDA merupakan cara negara mewujudkan kesejahteraan bersama seluruh rakyat. Hak Menguasai Negara (HMN) berada dalam domain yang bersifat publik, bukan sebagai pemilik yang bersifat privat. Konstitusi telah menggariskan prinsip penguasaan negara yang berdimensi hukum publik dan mengatur konsepsi penguasaan negara atas SDA yakni dalam Pasal 33 ayat (2) dan (3) UUD 1945. Negara memperoleh legitimasi untuk menguasai bumi, air, dan kekayaan alam yang terdapat di dalamnya karena status negara sebagai pencerminan organisasi kekuasaan bangsa. Sebagai konsekuensi, hak menguasai oleh negara merupakan hak yang tertinggi, yang berarti bahwa hak-hak atas tanah yang lain berada di

\footnotetext{
11 Yance Arizona, Konstitusionalisme Agraria., op. cit., hlm. 403.

${ }^{12}$ Inkuiri Nasional Komnas HAM, Hak Masyarakat Hukum Adat Atas Wilayahnya di Kawasan Hutan, Jakarta, Diterbitkan oleh Komnas HAM RI, 2016, hlm. ix.
} 
bawah hak menguasai negara. ${ }^{13}$

Konstitusi tidak menjelaskan lebih rinci apa dan bagaimana penjabaran konsepsi HMN yang tercantum dalam Pasal 33 ayat (3) UUD 1945. Salah satu penjelasan mengenai konsepsi HMN dapat dilihat dalam Pasal 2 UU No. 5 Tahun 1960 tentang Peraturan Dasar Pokok-pokok Agraria (UUPA). Menurut UUPA, HMN berasal dari doktrin bahwa negara merupakan organisasi kekuasaan seluruh rakyat yang menguasai kekayaan alam (bumi, air, udara dan kekayaan alam yang terkandung di dalamnya) pada tingkatan tertinggi.

Konsepsi HMN masih mengakar dalam peraturan perundang-undangan serta cara pandang yang menentukan tindakan-tindakan penyelenggara negara. Tidak jarang pengabaian terhadap hak-hak warga negara atas tanah dilakukan dengan dalih bahwa negara merupakan penguasa tanah yang tertinggi. Atas nama HMN pula pengingkaran terhadap hak-hak masyarakat hukum adat atas SDA yang ada di wilayahnya (tanah ulayat) dilakukan dan sekaligus memberi ruang gerak bagi pengambilalihan tanah secara besar-besaran dengan dalih pembangunan. Oleh karena itu, diperlukan pemaknaan baru yang bisa memberikan batasan mengenai konsepsi dan implementasi konsep HMN. ${ }^{14}$
Terdapat beberapa gagasan mengenai pembatasan HMN. Maria Sumardjono, Guru Besar Hukum Agraria UGM, menghendaki agar kewenangan negara yang bersumber pada hak menguasai negara dibatasi oleh dua hal. Pertama, pembatasan oleh UUD. Pada prinsipnya, hal-hal yang diatur oleh negara tidak boleh berakibat terhadap pelanggaran hakhak dasar manusia yang terjamin dalam UUD. Kedua, pembatasan yang bersifat substantif. Sesuai dengan Pasal 2 ayat (3) UUPA, maka semua peraturan pertanahan harus ditujukan untuk terwujudnya sebesar-besarnya kemakmuran rakyat, sedangkan ruang lingkup pengaturannya dibatasi oleh Pasal 2 ayat (2) UUPA. ${ }^{15}$

Gagasan lain disampaikan oleh Noer Fauzi dan Dianto Bachriadi yang menyatakan ada 4 (empat) pertimbangan terkait konsep HMN ini. Pertama, secara substansial, konsep HMN mengasumsikan penyerahan "kekuasaan masyarakat hukum adat atas tanah" kepada negara dimana tanah-tanah adat dijadikan tanah-tanah negara; Kedua, HMN berkedudukan lebih tinggi dari hak milik perdata warga negara, padahal negara dibentuk dengan maksud melindungi hak dari warga negaranya; Ketiga, mandat HMN untuk sebesar-besarnya kemakmuran rakyat tidak dijalankan dalam rangka penataan penguasaan atas tanah

\footnotetext{
${ }^{13}$ Winahyu Erwiningsih, Hak Menguasai Negara Atas Tanah (Yogyakarta: Total Media, 2009), hlm. 43.

${ }^{14}$ Ibid., hlm. 405.

${ }^{15}$ Ibid., hlm. 406.
} 
yang timpang. Bahkan sebaliknya, dengan dalih HMN, dilakukan pemberian hak-hak tanah baru yang sangat besar melalui hak pengusahaan hutan, kuasa pertambangan, hak guna usaha dan lainnya; Keempat penggunaan HMN melalui pemberian hak-hak baru tersebut, telah mengakibatkan konsentrasi penguasaan tanah di satu pihak dan sengketasengketa agraria yang berkepanjangan di lain pihak. ${ }^{16}$

Dengan berbagai gagasan tersebut, pemaknaan lain terhadap penguasaan negara atas tanah dan SDA lainnya harus dibahas satu napas dengan ketentuan konstitusi yang menjamin hak milik privat dan hak ulayat masyarakat adat. Relasi antara ketiga konsep hubungan hukum atas tanah tersebut berada dalam satu garis edar konstitusional di mana yang satu tidak menegasikan yang lain. ${ }^{17}$

\section{Penelusuran Sejarah dan Analisis Normatif Hukum Kehutanan dan Hukum Agraria}

\section{A. Masa Hindia Belanda}

Permasalahan MHA di kawasan hutan dan lahan merupakan pengejawantahan dari politik agraria yang berkembang sejak periode Hindia Belanda. Untuk memahami persoalan MHA di kawasan hutan dan lahan dengan utuh, diperlukan penjelasan tentang latar belakang bagaimana sejarah klaim negara atas kawasan hutan dan lahan. Konteks historis ini penting untuk memahami bagaimana akar penyebab pelanggaran hak-hak MHA atas wilayahnya di kawasan hutan dan lahan.

Di dalam internal pemerintah kolonial sendiri terjadi pertentangan pendapat dalam melihat kebijakan pertanahan yakni antara golongan liberal dan golongan konservatif. ${ }^{18}$ Kaum liberal menekankan pentingnya pemberian izin bagi perusahaan swasta untuk mengolah tanah, yakni dengan diakuinya hak kepemilikan perseorangan atas tanah yang dimiliki oleh orang Indonesia asli sehingga tanah tersebut dapat disewa atau dijual kepada pengusaha swasta. Sementara, kaum konservatif menentang pandangan ini dan menyatakan bahwa hak penduduk pribumi atas tanah didasarkan pada syarat-syarat yang bersifat asli, di mana penguasaan bersama atas tanah tidak dapat disamakan dengan konsep hak milik yang dikenal oleh Hukum Barat.

Agrarische Wet 1870 merupakan bentuk kompromi atas pengakuan pentingnya modal swasta dalam merintis usahausaha perkebunan. Namun, di sisi lain juga memberikan jaminan kepemilikan penduduk pribumi atas hak-hak tanah-

\footnotetext{
${ }^{16}$ Ibid., hlm. 406-407.

${ }^{17}$ Ibid., hlm. 408.

${ }^{18}$ Erman Rajagukguk, Hukum Agraria, Pola Penguasaan Tanah, Dan Kebutuhan Hidup (Jakarta, Penerbit Chandra Pratama, 1995), hlm. 25.
} 
nya, karena kepemilikan penduduk pribumi atas tanah adatnya terancam akan hilang seluruhnya apabila pengalihan tanah untuk perkebunan swasta tidak dibatasi. ${ }^{19}$

Untuk implementasi Agrarische Wet 1870, pada tahun yang sama dikeluarkan Koninklijk Besluit yang dikenal dengan Agrarische Besluit yang berlaku untuk Jawa dan Madura. Dalam hierarki peraturan perundang-undangan kolonial, Koninklijk Besluit berada di bawah UU, namun peraturan pelaksana ini dibutuhkan untuk memberlakukan sebuah UU di tanah jajahan. ${ }^{20}$ Pasal 1 Agrarische Besluit menyatakan bahwa semua bidang tanah yang tidak dapat dibuktikan kepemilikannya, berada di bawah kekuasaan (domain) negara. Di dalamnya juga diatur secara lebih terperinci mengenai hak-hak atas tanah dan pelepasan hak atas tanah, pada intinya adalah pemberlakuan dualisme hukum pertanahan. ${ }^{21}$

Pada tahun 1872, dikeluarkan dekrit oleh pemerintah Hindia Belanda yang menafsirkan Pasal 62 Regeringsreglement bahwa hak-hak dari penduduk pribumi tidak dipandang sebagai hak-hak yang sifatnya berdaulat, karena kedaulatan dari pemerintah Hindia Belanda tidak boleh dikurangi. ${ }^{22}$ Hak-hak dari penduduk pribumi harus dapat dibuktikan, bukan hak-hak yang dibuat-buat atau yang disebut pemerintah Hindia Belanda sebagai hak-hak yang imajiner yang hanya ada dalam gambaran penduduk pribumi itu sendiri. ${ }^{23}$ Pada periode akhir pemerintahan kolonial Belanda, konflik didominasi oleh sengketa tanah yang melibatkan klaim penduduk bahwa mereka memiliki hak atas hutan, sementara Pemerintah Kolonial menganggap tanah-tanah tersebut adalah milik negara. ${ }^{24}$ Dalam Pasal 2 Staatsblad No. 221 Tahun 1927 terdapat ketentuan bahwa yang termasuk hutan negara adalah tanah yang bebas dari hak ulayat pihak ketiga.

Hukum kolonial juga dikenal bersifat sangat eksploitatif, dualistik, feodalistik. Agrarische Wet 1870 memuat asas domeinverklaring yang pada intinya menyatakan bahwa semua tanah yang di atasnya tidak dapat dibuktikan hak eigendom oleh seseorang, adalah domain negara. ${ }^{25} \mathrm{Hal}$ ini sangat bertentangan dengan kesadaran hukum dan rasa keadilan dalam masyarakat. Wajar jika kemudian setelah proklamasi kemerdekaan timbul tuntut-

\footnotetext{
${ }^{19}$ Ibid., hlm. 26.

${ }^{20}$ Soetandyo Wignjosoebroto, Dari Hukum Kolonial Ke Hukum Nasional (Jakarta: Penerbit HuMa, 2014), hlm. 78 .

${ }^{21}$ Ibid., hlm. 79.

${ }^{22}$ Van Vollen Hoven, Orang Indonesia dan Tanahnya, Penerjemah Soewargono (Yogyakarta: STPN Press bekerja sama dengan Sayogyo Institute dan Tanah Air Beta, 2013), hlm. 87.

${ }^{23}$ Ibid., hlm. 88.

${ }^{24}$ Erman Rajagukguk, op. cit., hlm. 30.

${ }^{25}$ Yance Arizona, Konstitusionalisme Agraria., op. cit., hlm. 370.
} 
an agar segera diadakan pembaruan terhadap hukum agraria. ${ }^{26}$

\section{B. Masa Proklamasi}

Pasal 33 UUD 1945 dirancang sebagai landasan yang mengatur mengenai hubungan antara negara dengan SDA dan antara negara dengan rakyat. Negara memperoleh legitimasi untuk menguasai bumi, air, dan kekayaan alam yang terdapat di dalamnya karena status negara sebagai pencerminan dari organisasi kekuasaan bangsa. Sebagai konsekuensi, HMN merupakan hak yang tertinggi yang membawahi hak lainnya. ${ }^{27}$

Doktrin HMN yang tercantum dalam Pasal 33 ayat (3) UUD 1945 kemudian diterjemahkan ke dalam berbagai peraturan perundang-undangan terkait SDA. Penerjemahan Pasal tersebut ke dalam berbagai UU sektoral terkait SDA dipengaruhi oleh nilai dan kepentingan dari penyusunnya. ${ }^{28}$ Dengan adanya ketentuan penguasaan negara atas SDA yang diatur dalam konstitusi Pasal 33, dibuatlah berbagai peraturan perundang-undangan sektoral terkait dengan pengelolaan SDA.

Pada 1945-1959 pemerintah belum berhasil membuat UU Agraria Nasional yang bulat sebagai pengganti Agrarisc- he Wet 1870. Namun telah ada langkah untuk mengakhiri produk hukum agraria kolonial tersebut. Pertama, pengundangan berbagai peraturan agraria yang bersifat parsial, artinya, menyangkut bagian-bagian tertentu dari lingkup hukum agraria. Kedua, membentuk panitia-panitia perancang UU Agraria yang bulat dan bersifat nasional. ${ }^{29}$

\section{Masa UU Pokok Agraria}

Pasal 33 UUD 1945 yang mengatur mengenai penguasaan negara atas bumi, air, dan kekayaan alam yang terkandung di dalamnya, kemudian diterjemahkan lebih lanjut ke dalam sebuah UU yang mengatur tentang ketentuan-ketentuan pokok agraria (UU Nomor 5 tahun 1960 tentang Peraturan Dasar Pokok-Pokok Agraria, selanjutnya disebut UUPA) UUPA dimaksudkan sebagai landasan dari seluruh program baru perundang-undangan agraria. Sasaran hukum UUPA adalah meletakkan dasar bagi terciptanya hukum agraria yang dapat diterima secara nasional, guna menyederhanakan hukum serta pedoman penentuan hak rakyat atas tanah. ${ }^{30}$ UUPA lahir dan menciptakan Hukum Agraria Nasional berstruktur tunggal, yang berdasarkan atas Hukum Adat tentang tanah sebagai

\footnotetext{
${ }^{26}$ Moh. Mahfud MD, Politik Hukum di Indonesia (Jakarta: Rajawali Press, 2010), hlm. 119.

${ }^{27}$ Winahyu Erwiningsih, op. cit., hlm. 43.

${ }^{28}$ Yance Arizona, Perkembangan Konstitusionalitas Penguasaan Negara atas Sumber Daya Alam dalam Putusan Mahkamah Konstitusi, dalam Jurnal Konstitusi Vol. 8, No. 3, 2009, hlm. 258.

${ }^{29}$ Moh. Mahfud MD, Politik Hukum., op. cit., hlm. 120.

${ }^{30}$ Ibid., hlm. 175.
} 
hukum aslinya sebagian terbesar rakyat Indonesia. UUPA membawa perubahan yang bersifat fundamental bagi hukum pertanahan nasional, karena baik mengenai struktur perangkat hukumnya, maupun isinya, harus sesuai dengan kepentingan rakyat Indonesia serta memenuhi pula keperluannya menurut permintaan zaman.

UUPA menegaskan salah satu dasar hukum agraria nasional adalah hukum adat sebagaimana tersurat di dalam Pasal 5 UUPA yang menyatakan, "Hukum agraria yang berlaku di atas bumi, air, dan ruang angkasa adalah hukum adat..." Pemberian kedudukan yang demikian terhadap hukum adat menimbulkan pertanyaan akademis maupun praktis. Sebab dengan masih berlakunya hukum adat di samping UUPA, memberi kesan masih adanya sifat dualisme dalam masalah agraria. ${ }^{31}$ Namun ada juga sarjana yang menyatakan bahwa pemberian tempat kepada hukum adat dalam UUPA yang terjadi bukannya dualisme, tetapi sebaliknya meniadakan dualisme, seperti yang dikenal sebelum UUPA berlaku. ${ }^{32}$ Dengan pemberian tempat bagi hukum adat dalam UUPA, apalagi ditempatkan pada posisi dasar, maka hukum adat yang berlaku dalam kerangka UUPA dan bukan berlaku sendiri secara terlepas dari UUPA. Dengan kata lain, pasal-pasal dalam UUPA merupakan kristalisasi dari asas hukum adat sehingga UUPA itulah penjelmaan hukum adat yang sebenarnya. ${ }^{33}$

\section{Masa Orde Baru}

UUPA menghapus beberapa kebijakan hukum kolonial seperti Agrarische Besluit, Agrarische Wet, prinsip domeinverklaring, dan Buku ke-II Kitab UU Hukum Perdata sepanjang mengenai bumi, air, serta kekayaan alam yang terkandung di dalamnya. Namun, UUPA tidak mencabut sejumlah ordonansi yang mendasari kebijakan kehutanan. Artinya UUPA tidak sepenuhnya melakukan penyatuan hukum untuk mengakhiri pola sektoral dalam pengaturan di bidang agraria dan SDA. ${ }^{34}$

Dalam regulasi kehutanan, pola kebijakan sektoral tersebut kemudian dilanjutkan oleh pemerintahan orde baru dengan disahkannya Undang-Undang No. 5 Tahun 1967 tentang KetentuanKetentuan Pokok Kehutanan (UU Pokok Kehutanan). UU Pokok Kehutanan menerapkan sebagian ketentuan yang substansinya mengikuti kebijakan hukum kolonial, yakni Staatsblaad 1927 untuk Jawa dan Madura. UU Pokok Kehutanan bahkan tidak menyinggung keberadaan

\footnotetext{
${ }^{31}$ Ibid., hlm. 180.

${ }^{32}$ Ibid., hlm. 180.

${ }^{33}$ Ibid., hlm. 181.

${ }^{34}$ Yance Arizona, Konstitusionalisme Agraria, op. cit., hlm. 88.
} 
UUPA dan menghidupkan kembali prinsip domeinverklaring yang menetapkan bahwa negara adalah pemilik hutan dan Menteri Kehutanan memiliki kewenangan untuk menentukan wilayah mana saja yang termasuk kawasan hutan. ${ }^{35}$ Kelahiran UU Pokok Kehutanan ini sejak awal telah menimbulkan fragmentasi dalam pengaturan perundang-undangan di bidang agraria dan SDA yang sudah diatur sebelumnya dalam UUPA. Hal ini kemudian menghadirkan konflik antar institusi yang mengurusi agraria sehingga menimbulkan apa yang disebut sebagai ego sektoralisme. ${ }^{36}$

Dalam Pasal 5 UU Pokok Kehutanan dikatakan bahwa negara memiliki kewenangan untuk melakukan penguasaan atas hutan. Perumusan hak menguasai negara dalam UU Pokok Kehutanan dijadikan dasar bagi negara untuk melakukan dominasi kekuasaan yang tercermin dalam kewenangan pengelolaan hutan yang sentralistik dan tidak memberi hak kepada masyarakat untuk berperan serta dalam proses pengelolaan sumber daya hutan, dan negara tidak pula mengakui keberadaan hutan yang diatasnya terdapat hak-hak masyarakat hukum adat. Dalam kaitannya dengan keberadaan masyarakat hukum adat di sekitar kawasan hutan, Inpres No. 1 tahun 1976 tentang Sinkronisasi Pelaksanaan Tugas Bidang Keagrariaan dengan Bidang Kehutanan, Pertambangan, Transmigrasi dan Pekerjaan Umum mengatur mengenai mekanisme ganti rugi bagi pengambilalihan tanah masyarakat hukum adat yang berada di dalam areal yang telah diberi hak pengusahaan hutan diatasnya: ${ }^{37}$

Rezim Orde Baru telah secara luas menggunakan dan menyalahgunakan kewenangan pemerintah untuk memberikan konsesi-konsesi pertambangan, kehutanan, dan perkebunan; serta untuk pengadaan tanah bagi proyek-proyek pembangunan kawasan industri, infrastruktur dan lainnya. Pemerintah membentuk Departemen Kehutanan pada 1978 dan melalui kebijakan sentralistik, Menteri Kehutanan menunjuk lebih dari 120 juta hektare "kawasan hutan". Selanjutnya terbentuklah sistem ganda penguasaan dan pengelolaan pertanahan, yakni, pertama, apa yang disebut "kawasan hutan negara" berada di bawah yurisdiksi Departemen Kehutanan berdasarkan UU Pokok Kehutanan No. 5/1967 yang kemudian direvisi menjadi UU No. 41/1999; dan kedua, yang disebut tanah-tanah non-hutan yang berada di bawah yurisdiksi UUPA 1960 dikelola oleh Direktorat Jenderal Agraria, Depar-

${ }^{35}$ Ibid., hlm. 115.

${ }^{36}$ Ibid., hlm. 116.

${ }^{37}$ Boedi Harsono, Undang-Undang Pokok Agraria: Sejarah Penyusunan Isi dan Pelaksanaannya (Jakarta: Djambatan, Cet. III, 1970), hlm. 188-189. 
temen Dalam Negeri, yang selanjutnya pada tahun 1988 berubah menjadi Badan Pertanahan Nasional (BPN). ${ }^{38}$

Di wilayah tanah-tanah non-hutan, pemerintah Orde Baru menerapkan kebijakan "tanah untuk pembangunan" dengan mengandalkan apa yang disebut sebagai "pembebasan tanah". Pada mulanya, BPN dibentuk untuk meningkatkan kapasitas pemerintah dalam melayani kepentingan pengadaan tanah untuk proyek-proyek pembangunan itu. ${ }^{39}$

Pada masa Orde Baru terjadi perampasan tanah yang dilakukan oleh negara yang dilegitimasi oleh adanya konsepsi HMN. Artinya, bila pemerintah menyampaikan bahwa tanah yang menjadi objek konflik sebagai tanah negara dan negara punya hak untuk mengatur dan mempergunakannya atas nama pembangunan, maka rakyat harus minggir. ${ }^{40}$ Pada tataran yang lebih konkret, konsepsi HMN dipergunakan sebagai legitimasi untuk memberikan kekuasaan yang sangat besar, bahkan tanpa kontrol untuk menentukan alokasi sumber daya. Kekuasaan yang besar tersebutlah yang mendorong lahirnya konglomerasi di bi- dang ekonomi, perampasan tanah-tanah rakyat untuk konsesi perkebunan, kehutanan, dan pertambangan. ${ }^{41}$

Doktrin hak menguasai negara semasa orde baru memiliki dampak yang signifikan terhadap keberadaan hak ulayat masyarakat hukum adat. Pertama, masyarakat adat kehilangan wewenangnya atas tanah bersama sehingga sumber penghidupan utama hilang tanpa ada penggantinya. Kedua, hak menguasai yang diterapkan berbagai sektor yang berbeda (tanah, kehutanan, pertambangan) tidak menunjukkan kesamaan penafsiran tentang isi dan batas-batasnya. ${ }^{42}$ Monopoli kewenangan ini menurut Maria Sumardjono dapat mengaburkan peran negara untuk "menguasai" hutan menjadi "memiliki" hutan. ${ }^{43}$ Pengaburan peran Negara ini memiliki dampak yang signifikan dalam penguasaan hutan selama rezim orde baru.

Pada masa Orde Baru, penerjemahan konsepsi HMN ke dalam peraturan perundang-undangan di bidang agraria dan SDA, justru dijadikan dalih untuk melakukan perampasan tanah milik rakyat secara besar-besaran atas nama pem-

\footnotetext{
${ }^{38}$ Yance Arizona, Konstitusionalisme Agraria, op. cit., hlm. 445.

${ }^{39}$ Ibid., hlm. 446.

${ }^{40}$ Ibid., hlm. 41.

${ }^{41}$ Ibid., hlm. 131.

${ }^{42}$ Achmad Sodiki, Empat Puluh Tahun Masalah Dasar Hukum Agraria, Pidato Pengukuhan sebagai
} Guru Besar dalam Ilmu Hukum pada Fakultas Hukum Universitas Brawijaya Malang, 2000, hal. 13-14, sebagaimana yang dikutip dari Winahyu Erwiningsih, Hak Menguasai Negara, op. cit., hlm. 173.

${ }^{43}$ Maria SW Sumardjono, Revisi Undang-Undang Kehutanan, Kompas, 22 Juni 1999, hlm. 2, seperti yang dikutip dari Riyatno, Perdagangan Internasional dan Lingkungan Hidup, Cet 1, (Jakarta: Program Pascasarjana Fakultas Hukum Universitas Indonesia, 2009), hlm. 268. 
bangunan. Hal inilah yang menjadikan HMN menjadi sasaran kritik karena dijadikan legitimasi oleh Pemerintah Orde Baru untuk melakukan perampasan tanah secara legal atas nama pembangunan. Pemerintah Orde Baru telah melakukan pemburaman terhadap makna hak menguasai negara. Padahal apabila HMN diterjemahkan dengan lebih jernih, dimaksudkan untuk menempatkan negara dapat mengatur peruntukkan tanah, air, dan kekayaan alam yang terkandung di dalamnya demi sebesarbesarnya kemakmuran rakyat.

\section{E. UU Kehutanan Pasca Reformasi dan Putusan MK Atas Uji Materi UU Kehutanan}

Menurut UU. No. 41 Tahun 1999 tentang Kehutanan (UU Kehutanan), HMN meliputi kawasan hutan di seluruh Indonesia. Di samping hutan negara, diakui keberadaan hutan milik. Namun demikian, keberadaan hutan adat tidak diakui. Hal ini dikarenakan menurut Ketentuan Umum butir 6 UU. No. 41/1999 tentang Kehutanan, hutan adat adalah hutan negara yang berada di wilayah masyarakat hukum adat. Dalam konsepsi hukum kehutanan, hanya dikenal dua status hutan yakni hutan negara dan hutan hak. Sementara dalam konsepsi hukum tanah nasional yang digariskan dalam UUPA mengenal tiga entitas berkenaan dengan status tanah, yakni tanah negara, tanah hak, dan tanah ulayat. Menurut Maria Sumardjono terdapat perbedaan tegas antara konsepsi hukum tanah nasional dan konsepsi hukum kehutanan: ${ }^{44}$

UU Kehutanan (terakhir diubah dengan UU. No. 19 Tahun 2004) merupakan undang-undang di bidang tanah dan SDA lainnya yang paling sering diuji ke Mahkamah Konstitusi (MK). Salah satu perkara monumental adalah PUU No. 35/PUU-X/2012 (selanjutnya disebut Putusan MK 35) yang menguji konstitusionalitas masyarakat hukum adat di dalam kawasan hutan dan persoalan mengenai hutan adat termasuk ke dalam hutan negara menurut UU Kehutanan. Dalam pertimbangannya, MK menyatakan bahwa masyarakat hukum adat secara konstitusional merupakan subjek hukum yang diakui dan dihormati sebagai penyandang hak. UU Kehutanan (1999) telah memperlakukan masyarakat hukum adat secara inkonstitusional sebagai subjek hukum terkait dengan hutan secara berbeda dengan subjek hukum yang lain. Negara menguasai baik atas tanah maupun atas hutan. Pemegang hak atas tanah juga memegang hak atas hutan, tetapi masyarakat hukum adat tidak secara jelas pengaturan tentang haknya atas tanah maupun hutan. ${ }^{45}$

\footnotetext{
${ }^{44}$ Maria Sumardjono, Tanah Dalam., op. cit., hlm. 172.

${ }^{45}$ PUU No. 35/PUU-X/2012 mengenai pengujian UU. No. 41 Tahun 1999 tentang Kehutanan.
} 
Melalui putusan tersebut, MK mengeluarkan hutan adat dari kategori hutan negara, namun tidak menjadikan hutan adat ke dalam kategori khusus seperti yang dimohonkan oleh Para Pemohon, melainkan memasukkannya ke dalam kategori hutan hak. Implikasi dari Putusan MK 35 ini adalah masyarakat hukum adat memiliki wewenang untuk mengatur peruntukan, fungsi, dan pemanfaatan tanah ulayat dan hutan adat yang ada di wilayahnya melalui penetapan hutan adat.

Namun Pasca Putusan MK35, pengakuan hutan adat di Indonesia mengalami keterlambatan dalam implementasinya. Myrna Safitri dalam Dividing the Land: Legal Gaps in the Recognition of Customary Land in Indonesian Forest Areas, memperlihatkan bahwa terdapat tiga faktor utama yang menyebabkan keterlambatan pengakuan hutan adat di Indonesia, khususnya pasca Putusan MK 35. Ketiga faktor tersebut tediri: a) inkosistensi hukum nasional terkait payung hukum pengakuan masyarakat adat dan wilayahnya; b) masih bertahannya pola pikir diantara birokrat kehutanan yang memandang bahwa 'kawasan hutan' adalah hanya hutan negara; dan c) kuatnya motivasi politik-ekonomi diantara pemerintah daerah untuk memprioritaskan alokasi la- han untuk investasi skala besar daripada pengakuan wilayah adat. ${ }^{46}$

\section{F. Peraturan Perundang-Undangan Mengenai Kawasan Hutan dan Lahan Pasca Putusan MK 35}

Putusan MK 35 memberikan dampak pada pembaruan hukum di tingkat nasional, serta mendorong hadirnya berbagai produk hukum daerah mengenai masyarakat hukum adat, meskipun belum menyeluruh ada pada setiap provinsi maupun kabupaten/kota. Dari sisi bentuk hukumnya, produk hukum daerah tersebut berbagai macam bentuknya mulai dari peraturan daerah, peraturan kepala daerah, dan keputusan kepada daerah. Dari sisi materi muatan juga beragam mulai pengaturan mengenai kelembagaan adat dan peradilan adat, keberadaaan masyarakat adat, desa adat, maupun hak masyarakat adat terhadap wilayah, tanah, hutan, dan SDA lainnya. ${ }^{47}$

Pasca Putusan MK 35, terjadi perubahan dalam pemberian hak akses dan pemanfaatan bagi masyarakat lokal dan/atau masyarakat hukum adat. Perubahan tersebut paling tidak dapat dilihat dari empat skema perubahan yang tengah berjalan berdasarkan peraturan perundang-undangan.

\footnotetext{
${ }^{46}$ Sebagaimana dikutip dari Muki T. Wicaksono dan Malik, “Konteks Poltik Hukum Di Balik Percepatan Penetapan Hutan Adat: Catatan Ke Arah Transisi” 2019, Jurnal Hukum Lingkungan Indonesia Vol. 4, Februari, (2018), hlm. 29.

${ }^{47}$ Malik, Yance Arizona, dan Mumu Muhajir, "Analisis Tren Produk Hukum Daerah mengenai Masyarakat Adat”, Policy Brief Epistema Institute, Vol. 01, (2015), hlm. 1.
} 
Pertama, dalam hal penyelesaian hak pihak ketiga melalui Peraturan Menteri Kehutanan (Permenhut) No. 44 Tahun 2012 tentang Pengukuhan Kawasan Hutan yang telah diubah melalui Permenhut No 62 Tahun 2013. Peraturan ini menjelaskan bahwa penataan batas kawasan hutan adalah kegiatan yang meliputi kegiatan identifikasi dan penyelesaian hak-hak pihak ketiga yang diantaranya merupakan masyarakat hukum adat di sekitar kawasan hutan. Keberadaan masyarakat hukum adat tersebut ditetapkan dengan Peraturan Daerah Provinsi atau Kabupaten/Kota. Peraturan Daerah tersebut memuat letak dan batas wilayah masyarakat hukum adat yang dinyatakan secara jelas dalam peta wilayah masyarakat hukum adat. Sebagian atau seluruh wilayah masyarakat hukum adat berada dalam kawasan hutan, maka dikeluarkan dari kawasan hutan. Tata cara mengeluarkan masyarakat hukum adat dari Kawasan Hutan, diatur dengan Peraturan Direktur Jenderal.

Kedua, dalam hal pemulihan hak komunal melalui Peraturan Menteri ATR/ BPN No. 10 Tahun 2016 tentang Tata Cara Penetapan Hak Komunal atas Tanah Masyarakat Hukum Adat dan Masyarakat Yang Berada Dalam Kawasan Tertentu (Permen Hak Komunal). Peraturan ini memberikan mandat kepada pemerintah daerah untuk membentuk
Tim Inventarisasi Penguasaan, Pemilikan, Pengelolaan, dan Penggunaan Tanah (Tim IP4T) untuk mengidentifikasi klaim masyarakat adat dan masyarakat lokal pada kawasan hutan dan wilayah perkebunan. Hasil inventarisasi Tim IP4T kemudian diikuti dengan penerbitan Sertifikat Hak Komunal oleh BPN. Namun hingga saat ini belum ada satupun sertifikat hak komunal yang telah diberikan oleh pemerintah atas dasar Permen Hak Komunal. ${ }^{48}$

Ketiga, pemulihan hutan adat melalui Peraturan Menteri LHK No. 32 Tahun 2015 tentang Hutan Hak. Peraturan ini berisi prosedur untuk pengakuan hutan adat sebagai tindak lanjut dari Putusan MK 35. Di dalamnya berisi tanggung jawab kementerian untuk memfasilitasi pemerintah daerah menghasilkan produk hukum daerah mengenai masyarakat dan memberikan insentif bagi masyarakat pengelola hutan adat.

Keempat, skema perhutanan sosial melalui Peraturan Menteri LHK No. 83 Tahun 2016. Untuk distribusi lahan dan hutan kepada warga lewat skema perhutanan sosial, pemerintah memasang target awal sejumlah 12,7 juta hektare. Belakangan target ini direvisi menjadi 4,39 juta hektar sampai dengan 2019. Di sisi lain, realisasi hutan adat baru 28.286,34 hektar (sekitar 1\%) dari skema perhutanan sosial. Data KLHK (4 Ma-

\footnotetext{
${ }^{48}$ Ibid., hlm. 9
} 
ret 2019), capaian perhutanan sosial sejumlah 2.566.708,15 hektar, terdiri dari 1.281.049,18 hektar hutan desa, 645.593,82 hutan kemasyarakatan, 331.993,68 hektar hutan tanaman rakyat, 549.785,13 hektar kemitraan kehutanan dan 28.286,34 hektar hutan adat. ${ }^{49}$

Selain itu, juga terdapat Peraturan Menteri LHK No. 34/2017 tentang Pengakuan dan Perlindungan Kearifan Lokal dalam Pengelolaan SDA dan Lingkungan Hidup dan Sumber Daya Genetik. Dengan melibatkan masyarakat hukum adat dalam tata kelola kawasan konservasi, secara langsung negara telah hadir merespons dua isu penting di kawasan konservasi, yakni: a) kriminalisasi masyarakat adat dalam kawasan hutan; dan b) jaminan akses kelola masyarakat hukum adat di dalam kawasan konservasi yang lebih inklusif. Masyarakat diposisikan sebagai subjek atau pelaku utama dari berbagai model pengelolaan kawasan hutan. ${ }^{50}$

Namun selain mengalami kemajuan yuridis, beberapa peraturan perundangundangan yang mengatur mengenai hutan dan lahan juga mengalami kemunduran dalam hal pemberian akses dan pemanfaatan bagi masyarakat hukum adat. Diantaranya tercatat melalui Peraturan Presiden No. 88 Tahun 2017 ten- tang Penyelesaian Penguasaan Tanah dalam Kawasan Hutan. Perpres ini memiliki beberapa kelemahan yang akan memicu konflik baru terhadap keberadaan masyarakat hukum adat.

Alasannya, Pertama, Perpres ini membuat rancu definisi kawasan hutan. Perpres ini masih menggunakan frase "ditunjuk" dalam mendefinisikan kawasan hutan dan bukan menggunakan frase "ditetapkan" seperti yang menurut UU No. 41/1999 tentang Kehutanan merupakan tahap akhir dalam proses pengukuhan kawasan hutan sebagaimana dimaksud dalam Putusan MK No. 45/2011.

Kedua, Perpres ini juga membuat penyederhanaan pola penyelesaian bagi penguasaan dan pemanfaatan tanah di kawasan hutan dengan fungsi konservasi. Setelah kawasan hutan ditunjuk, pola penyelesaiannya hanya dengan cara dipindahkan (resettlement) dan sebelum kawasan hutan ditunjuk, hanya terdapat pola penyelesaian berupa dikeluarkan dari kawasan hutan. Program resettlement ini mengancam masyarakat dan berpotensi menyebabkan kriminalisasi. Sedangkan berdasarkan data Aliansi Masyarakat Adat Nusantara, potensi wilayah adat yang terancam resettlement karena berada di dalam kawasan konser-

${ }^{49}$ Lusia Arumingtyas, "Penetapan Hutan Adat Hanya 1\% dari Realisasi Perhutanan Sosial".www. mongabay.co.id/2019/03/27/penetapan-hutan-adat-hanya-1-dari-realisasi-perhutanan-sosial/, diakses tanggal 30 Mei 2019.

${ }^{50}$ Muki T. Wicaksono dan Malik, Konteks Politik Hukum., op. cit., hlm. 42-43. 
vasi seluas 1,62 juta hektare. Angka itu merupakan $20 \%$ dari 8,2 juta hektare wilayah adat yang telah terdaftar.

Alasan yang ketiga, Perpres ini mengancam hidup MHA yang berada di 1,62 juta hektare wilayah adat di kawasan konservasi. Hal ini dikarenakan dalam ketentuan Perpres ini mengatakan bahwa pola penyelesaian untuk bidang tanah yang dikuasai dan dimanfaatkan setelah bidang tanah tersebut ditunjuk sebagai kawasan hutan dengan fungsi konservasi dilakukan melalui resettlement. Jika ketentuan ini diterjemahkan, maka keberadaan MHA yang berada di wilayah konservasi harus dikeluarkan. Kebijakan konservasi di sini lebih menempatkan negara sebagai aktor utama konservasi. Padahal MHA yang hidup menyatu dengan alam juga memiliki hak biokultural yang harus mulai diperkenalkan sebagai aktor yang memelihara keanekaragaman hayati di wilayah konservasi.

Keempat, Perpres ini menciptakan ketidakjelasan dan menghambat proses pengukuhan kawasan hutan; perhutanan sosial, penetapan hutan adat; penetapan hak komunal. Hal ini dikarenakan Perpres ini mengatur bahwa penunjukan kawasan hutan adalah penetapan awal peruntukan suatu wilayah tertentu se- bagai kawasan hutan. Ketentuan dalam Perpres ini bertentangan dengan Putusan MK 35 dan Permenhut No. 44 Tahun 2012 tentang Pengukuhan Kawasan Hutan. Proses pengukuhan kawasan hutan termasuk di antaranya perhutanan sosial, penetapan hutan adat, dan penetapan hak komunal dilakukan melalui rangkaian kegiatan yakni melalui penunjukan, penataan batas, dan penetapan kawasan hutan.

Kelima, Perpres ini mengatur pengakuan MHA harus dengan Perda. Artinya, menutup peluang menggunakan instrumen hukum pengakuan melalui Keputusan Kepala Daerah dan Sertifikat/ SK Hak Komunal. ${ }^{51}$

Kemunduran Pemerintah dapat juga dilacak dalam keberpihakannya atas pengakuan keberadaan MHA seperti yang ditemui dalam Perpres Nomor 86 Tahun 2018 tentang Reforma Agraria, yang tidak menyebutkan MHA sebagai subjek reforma agraria. Padahal, peraturan ini diharapkan menjadi tonggak penting mengatasi ketimpangan dan ketidakadilan penguasaan lahan di Indonesia. Perpres ini memang menyebutkan bahwa hak ulayat bukan bagian dari Tanah Obyek Reforma Agraria. ${ }^{52}$ Namun, mengatur tanah bekas HGU, tanah bekas erfpacht, dan tanah dari pelepasan kawa-

${ }^{51}$ AMAN, Epistema Institute, HuMa, “Opini Hukum Dari Reformasi Kembali ke Orde Baru: Tinjauan Kritis Peraturan Presiden No. 88 Tahun 2017", (2017), hlm. 6.

${ }^{52}$ Nurul Firmansyah. "Perpres Reforma Agraria Tanpa Masyarakat Adat http://www.mongabay. co.id/2018/11/05/ perpres-reforma-agraria-tanpa- masyarakat-adat/, diakses pada 28 November 2018. 
san hutan sebagai objek reforma agraria yang berpotensi menjadi tumpang tindih dengan hak ulayat atau berpotensi menyebabkan konflik.

\section{Kesimpulan}

Kerentanan posisi masyarakat adat terjadi akibat konsekuensi dari ketidakjelasan pengelolaan tenurial. Hal ini terjadi salah satunya disebabkan oleh instrumen hukum yang tidak memihak pada pengakuan keberadaan MHA. Penerapan Hak Menguasai Negara harus dimaknai ulang dengan menempatkan Pasal 33 UUD 1945 dalam satu tarikan nafas dengan ketentuan lain dalam konstitusi yang mengakui perlindungan terhadap hak asasi manusia dan pengakuan konstitusional atas keberadaan masyarakat hukum adat. 


\section{DAFTAR PUSTAKA}

\section{Peraturan Perundang-Undangan}

Indonesia, Undang-Undang Dasar Negara Republik Indonesia tahun 1945. - Undang-Undang Peraturan Dasar Pokok-Pokok Agraria. UU No. 5 Tahun 1960. LN No. 104 Tahun 1960. TLN No. 2043.

\section{Undang-Undang Ketentuan-}

Ketentuan Pokok Kehutanan. UU No. 5 Tahun 1967. LN No. 8 Tahun 1967; TLN No. 2823.

Undang-Undang Nomor Kehutanan. UU No. 41 Tahun 1999. LN 167, tahun 1999. TLN 3888.

Peraturan Presiden No. 88 Tahun 2017 tentang Penyelesaian Penguasaan Tanah dalam Kawasan Hutan.

Peraturan Presiden Nomor 86/ 2018 tentang Reforma Agraria.

Instruksi Presiden No. 1 Tahun 1976 tentang Sinkronisasi Pelaksanaan Tugas Bidang Keagrariaan dengan Bidang Kehutanan, Pertambangan, Transmigrasi dan Pekerjaan Umum.

\section{Putusan Pengadilan}

PUU No. 45/PUU-IX/2011 mengenai pengujian UU. No. 41 Tahun 1999 tentang Kehutanan.

PUU No. 35/PUU-IX/2012 mengenai pengujian UU. No. 41 Tahun 1999 tentang Kehutanan.

\section{Buku}

Arizona, Yoga. Konstitusionalisme Agraria, Yogyakarta: STPN Press, 2014.

Arizona. Mahkamah Konstitusi dan Reformasi Tenurial Kehutanan, Jakarta, 2013.

Bastiat, Frederic. Hukum, diterjemahkan oleh Zaim Rofiqi, Jakarta: Freedom Institute, 2010.

Erwiningsih, Winahyu. Hak Menguasai Negara Atas Tanah.Yogyakarta: Total Media. 2009.

Harsono, Boedi. Undang-Undang Pokok Agraria: Sejarah Penyusunan Isi dan Pelaksanaannya, Jakarta:Djambatan, Cet. III, 1970.

Inkuiri Nasional Komnas HAM. Hak Masyarakat Hukum Adat Atas Wilayahnya Di Kawasan Hutan. Jakarta: Komnas HAM RI, 2016.

Moh. Mahfud MD. Politik Hukum di Indonesia, Jakarta: Rajawali Press, 2010.

Rahardjo, Satjipto. Hukum Adat Dalam Negara Kesatuan Republik Indonesia, dalam Masyarakat Hukum Adat: Inventarisasi Dan Perlindungan Hak, Jakarta: Komnas HAM, MK RI, Departemen Dalam Negeri RI, 2005.

Rajagukguk, Erman. Hukum Agraria, Pola Penguasaan Tanah, Dan Kebutuhan Hidup, Jakarta: Penerbit Chandra Pratama, Cet. Peratama, 1995.

Riyatno. Perdagangan Internasional dan Lingkungan Hidup, Cet 1, Jakarta: Program Pascasarjana Fakultas Hukum Universitas Indonesia, 2009. 
Soewargono, Yogyakarta: STPN Press bekerja sama dengan Sayogyo Institute dan Tanah Air Beta, 2013.

Sumardjono, Maria. Tanah Dalam Perspektif Hak Ekonomi, Sosial, Dan Budaya, Jakarta,: Kompas, 2009.

Van Volleh Hoven. Van Vollen Hoven, Orang Indonesia dan Tanahnya, Penerjemah

Wignjosoebroto, Soetandyo.Dari Hukum Kolonial Ke Hukum Nasional, Jakarta: Penerbit HuMa, 2014.

\section{Artikel Jurnal/Media Massa}

AMAN, Epistema Institute, HuMa, Opini Hukum: Dari Reformasi Kembali Ke Orde Baru, Tinjauan Kritis Peraturan Presiden No. 88 Tahun 2017, Oktober 2017.

Arizona, Perkembangan Konstitusionalitas Penguasaan Negara atas Sumber Daya Alam dalam Putusan Mahkamah Konstitusi, dalam Jurnal Konstitusi Vol. 8, No. 3, 2009.

Asep Yunan Firdaus dan Emila Wildawati, Laporan Evaluasi Kemajuan dan Capaian Reforma Kebijakan Penguasaan Tanah dan Kawasan Hutan di Indonesia, Jakarta, Epistema Institute.

Malik, Yance Arizona, dan Mumu Muhajir, Policy Brief Epistema Institute Vol. 01/2015: Analisis tren produk hukum daerah mengenai Masyarakat Adat.

Muki T. Wicaksono dan Malik, Konteks Poltik Hukum Di Balik Percepatan Penetapan Hutan Adat: Catatan Ke
Arah Transisi 2019, Jurnal Hukum Lingkungan Indonesia Vol. 4, Februari 2018.

Yance Arizona, Malik, Irena Lucy Ishimora, Pengakuan Hukum Terhadap Masyarakat Adat: Tren Produk Hukum Darah dan Nasional Pasca Putusan MK 35/PUU X/2012, Epistema Outlook 2017.

\section{Lain-lain}

Apriando, Tommy. "Kajian UGM: 2,8 Juta Hektar Kebun Sawit di Kawasan Hutan, 65\% Milik, Solusinya?". htt p: / / www . mongabay.co. id/2018/11/04/kajian-ugm-28-jutahektar-kebun-sawit-di-kawasanhutan-65-milik-pengusaha-solusinya/, diakses pada 28 November 2018

Arumingtyas, Lusia. "Penetapan Hutan Adat Hanya 1\% dari Realisasi Perhutanan Sosial". https://www.mongabay.co.id/2019/03/27/penetapanhutan-adat- hanya-1-dari-realisasiperhutanan-sosial/, diakses pada 30 Mei 2019.

Damarjati, Danu. “Menteri LHK Beberkan Hasil Atasi Ketimpangan Penguasaan Hutan". https://news.detik. com/berita/d-3952129/menteri-lhkbeberkan-hasil-atasi- ketimpanganpenguasaan-hutan, diakses pada 23 April 2019

Firmansyah, Nurul. "Perpres Reforma Agraria Tanpa Masyarakat Adat http:// ww w.mongabay.co. id/2018/11/05/perpres-reformaagraria-tanpa- masyarakat-adat/, diakses pada 28 November 2018. 